\title{
Modular principle of exploitation of drainage systems for implementation of agricultural potential of ameliorated lands of the Western Polisia
}

\author{
Yu. Tarariko, \\ Corresponding Member of the National Academy of Sciences of Ukraine, Doctor of Agricultural \\ Sciences \\ M. Stetsiuk, \\ Sarny experimental station NAAS \\ N. Mozol, \\ Institute of Water Problems and Land Reclamation NAAS
}

The purpose. To justify directions of redesign and engineering modernization of working MS in the Western Polisia for their efficient exploitation in modern conditions and to determine main routes of support of agrarian production, ensuring the maximum utilization of agricultural potential of ameliorated lands. Methods. Statistical, field, computer simulation. Results. Modular approach is offered of differentiation of operation of system Sarnenska DS with decentralized control on each module with hydroregulator of level. Simulation modeling of scripts of support of production on ameliorated lands is realized, economic assessment of their agricultural potential is made. Conclusions. It is proved that at application of modular approach of exploitation of MS it is possible to sustain necessary level of soil waters of sewed soils within the limits of $0,6-1,1 \mathrm{~m}$ during vegetative period. Results of simulation modeling of support of agrarian production on prototype system show that at efficient exploitation of MS and secured water-aerial regime of lands profitableness can grow in 4 times. Implementation of the offered method in analogous systems of Western Polisia will allow using efficiently more than 1,1 million hectares of available reclaimed lands with the maximum level of profitableness up to 12 thousands hrn/hectare.

Key words: hydroreclamative system, simulation modeling, agricultural potential.

\section{LAND WESTERN POLISSYA}

The practice of agriculture at the reclaimed lands of the Western Polissya of Ukraine testifies to the fact that under the current economic conditions net profit water hectare is on the average $500-800$ $\mathrm{UAH} / \mathrm{ha}$ [1]. Given the fact that the proportion of drained land in the total area of agricultural land of Polissya is $37.5 \%$, and in the regions of the Western woodlands is generally over $50 \%$ [2], the level of profitability cannot attract investments in reconstruction of drainage systems.

Unfortunately, the current technical condition and the level of exploitation of reclamation systems (RS) also do not meet the needs of modern agricultural production. Especially against the background of climate change, the likelihood of years with insufficient moisture supply increased from $10 \%$ to $20 \%$ [1], and in the second half of the vegetative period of deficiency of moisture is observed constantly.

Built in 1671 systems on an area of 3.2 million hectares are technically sound to $33.8 \%$, meaning that only 1.08 million hectares of reclaimed land is guaranteed the ability to regulate the water regime of soils. [2]. Therefore, recovery efficiency of reclamation systems as a condition of increase of efficiency of use of available agroresource capacity refers to the number of priorities can be solved by reconstruction and modernization of existing engineering infrastructure of these systems.

The purpose of the research. To justify the ways of reconstruction and technical modernization of existing MS Western woodlands for their effective operation in modern conditions of managing and to 
determine the main directions of agricultural production, ensuring maximum utilization of agroresource capacity of reclaimed lands.

The methodology of research. The study was comprehensive and included field investigations of the status of the vehicle, stationary studies to determine the productivity of reclaimed soil, computer simulation modeling of different scenarios of management of agricultural production.

Field studies were conducted on a typical reclamation system "Chemerne" Sarny research station (SRS) (Rivne region) IWPiM NAAN in 2016, the System is constructed in 1924, its reconstruction was carried out in 1939, 1958, 1975 Major reconstruction of the system were designed for the conversion from drainage to drainage-moisturizing, as well as on the deepening of open channels, the device control structures. After modernization, the system operation was complicated because of the large number of technological operations. The work of all components of the system designed interdependencies that complicate the management of the water regime of soils on separate sites. The situation when the disability of one structural element (structure, reservoir, channel) affects the entire system. For example, muddy or open channel construction idle-field wired network first order prevents drainage of excess moisture from adjacent channels at the confluence of channels in the older procedure, with omission of water consumption $25 \%$ th security and causing more flooding. Operating system comes to allotment spring flood waters beyond the reclaimed agricultural landscapes, thus irrevocably lost moisture reserves required for regulation RGV during dry summer months. Most Irrigation and drainage systems operated in the same mode as an example of differentiation VTS systems in a modular fashion can unify the entire humid zone.

The area of research is complicated drainage basins - typical for the region phenomena of degradation due to low surface reclamation operation system (MS). Land use ratio is 0.59 , that is used by 259 hectares of the existing 439 hectares (net) of reclaimed farmland.

Full-scale studies were conducted to analyze the level of exploitation and modes of leading channels and hydraulic structures for water regime drained land in dry periods; establish a link between the level of groundwater (RGV), precipitation and runoff drainage module; Analysis of soil water regime in the deficit rainfall.

In the existing drainage systems SDS was typical plot of 20 hectares and 7 hectares and completed the repair and maintenance work on bringing inter-farm and farm to network design parameters. Structural and technological modernization of selected objects is made taking into account the relief of conditions in a modular fashion, in which the soil water regime management is performed separately for each module that is not hydraulically connected to other areas [3]. Done partial modernization of existing and installation of new structures, including sharpen hidrorehulyators RGV on a wired network.

In typical experimental plots after the passage of the flood was accumulation local flow by the staff of the collector-drainage network and by subsoil moistening used in the future for water regime drained soil. Detailed methodology for water regime described in the paper "technology water regime of land drained using drainage flow" [4].

Assessment agroresource potential of the area was carried out using the information base for longterm steady crop experiment SDS "To develop a rational structure of sown areas and crop rotation, the system of cultivation and fertilization in crop rotations aimed at improving soil fertility, conservation of organic matter of peat and performance peaty soil" Year bookmarks - 1955 . The results were used for computer modeling of optimal scenarios for agricultural production that enable Option Number agroresource to realize the potential of reclaimed territory Sarny RS.

Results. With the aim of eliminating structural and technological deficiencies in the existing land improvement systems and restoration of on-farm network have developed standard schemas newest designs of irrigation systems to the modular principle with decentralized control of RGV on each module (Fig .1), equipped toregulation level (Fig.2). 


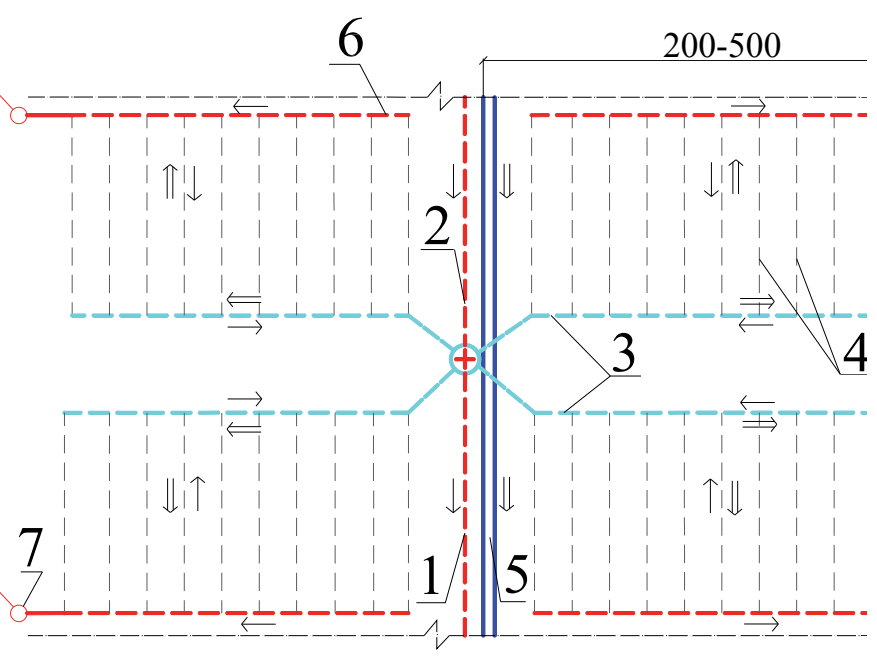

1 - waste collector; 2 - water-regulating unit with hidrorehulyators RGV; 3 - drainage-moisture collector; 4 drain; 5 - moisturizing channel; 6 - the aeration manifold; 7 - ventilating pit

Fig. 1 Drying and a moisturizing module with the combined regulatory network

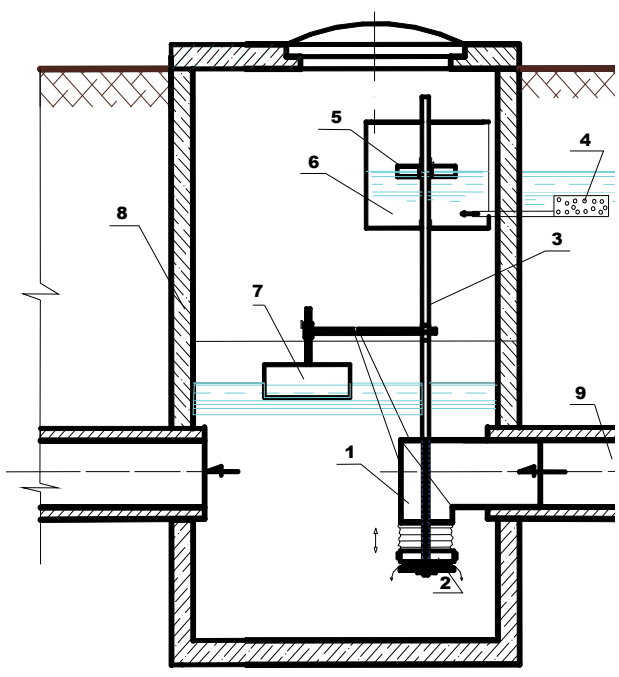

1 - casing; 2 - valve; 3 - rod; 4 - filter; 5,7 - level sensors; 6 - float chamber; 8 well; 9 - drainage collector

Fig. 2 Scheme toregulate RGV, double-

Established in Pre-and the growing season in areas controlled system RGV in April-May fluctuated in the range of 0.6 to $0.85 \mathrm{~m}$, and in May and June - from 1.05 to $1.15 \mathrm{~m}$ from the ground, in control area within 1,0-1,55 0,45-1,1 and $\mathrm{cm}$ respectively. Stabilization given water regime of the soil in dry periods was provided through the accumulation of drainage runoff in drainage collector network, and the timing of withdrawal of excess water in wet periods were 2-3 days, the control - longer than 7 days. These terms diversion of excess moisture (2-3 days) is acceptable in the cultivation of basic crops and do not lead to the possible loss of their crops.

Studies show that structural and technological modernization of the existing network of drainage systems in a modular fashion VTS allows you to quickly adjust the water regime of reclaimed land, thus increasing the effective area of agricultural use of reclaimed land from 259 hectares to 410 hectares ( $0.93 \mathrm{CLU}$ ).

Based on the data obtained in the evaluation of potential study area agroresource Sarny RS found that the main precondition for the intensification of production research facility is to optimize water and air and soil nutrient regimes with regard to crop rotation factor that ultimately allows you to increase the productivity of arable land natural background fertility of 3.6 times. At the level of patient experiment widespread modern industrial practice area modeling version without fertilizers. At this stage the estimated effectiveness of growing commodity grain and industrial crops - barley and potatoes.

On the basis of these choices experiment conducted simulation of various scenarios of reclaimed farmland in order to identify the most promising of them. During this simulation placed the most appropriate and balanced version of a particular agricultural enterprise (software systems "agroecosystems" and "Modeling of organic production" [5]).

Model №1 «Current practice (control)" - growing potatoes and barley on natural background fertility in accordance with the yield of 14.5 and $1.8 \mathrm{t} / \mathrm{ha}$.

Model №2 «Optimizing water-air regime of soil (Control - good years)." Consider the feasibility for establishing recovery of MS for modern crop branch structure while optimizing the water-air regime of soil in the most favorable years of modeling work MS, the maximum yield of barley under control is $2.9 \mathrm{t} / \mathrm{ha}$, potatoes - $19.6 \mathrm{t} / \mathrm{ha}$.

Model №3 «Optimization of nutrient and water-air regime of soil (NPK + Sd - good years)." The impact of the simultaneous optimization of water and air and soil nutrient regimes in terms of payback for MS 
contemporary practice. A similar previous yield of barley in the most auspicious year against the backdrop of fertilizer $3.7 \mathrm{t} / \mathrm{ha}$, potatoes - $35.8 \mathrm{t} / \mathrm{ha}$.

Under Model 2 №1 rotation of the fields, according to the area of 500 hectares will be collected on the average 7.3 thousand. tons of potatoes and 0.9 thousand. tons of barley. According to the scenario models №2, simulating the work of MS, these figures increase to 9.8 and 1.4 thousand. T, and for the optimization of water and air and soil nutrient regimes (Model №3) increase to 17.9 and 1, 9 thousand. t., respectively.

Economic evaluation agroresource potential of the investigated object were carried out on the basis of indicators obtained in the result of simulation of prospective scenarios of its development. To characterize the efficiency of a particular model of the development of productive activities were used such as profitability, payback period, revenue, cost, profit. Production costs include: technology costs in crop production for the growing of crops and the operation of the vehicle.

For calculations were used the data of statistical information on cost of cultivation of crops and the prices of their implementation [6].

Modeling the sectorial structure according to the planned objectives involves the following capital costs: according to modern practices of agricultural production and operation of the vehicle capital will amount to UAH 10 million. 1 thousand hectares of arable land or 10 thousand UAH./ha. Reconstruction (construction) of the vehicle will increase this figure to 80 million UAH. and for the joint improvement of water, air and nutrient regimes of the soil - up to $90 \mathrm{mln}$.

For crop management practices a profit on the natural background of soil fertility can be up to 3 thousand $\mathrm{UAH} / \mathrm{ha}$. Regulation of water-air regime in these circumstances will allow to double this figure. Joint optimization of water-air and nutrient regimes of the soil will be accompanied by a yield increase of up to 12 thousand $\mathrm{UAH} / \mathrm{ha}$.

The minimum costly option with the construction of storage facilities for crop products and the acquisition of complex techniques for qualitative and timely fulfillment of field works is the payback period - 3.4 years, but the profitability level is relatively low (Model \# 1). The reconstruction of the MS doubles net profit, but most cost of the project determines too large a payback period of 14 years (Model 2). The analysis also showed the value of increasing the fertility of reclaimed land. Thus, systematic application of fertilizers in terms of regulation of water-air regime of the soil allows to reduce the payback period TS half (Model 3) (Fig. 3).

Therefore, if crop specialization (grain, industrial), the reconstruction of the vehicle and gives the chance to double net profit, however, the payback period will be lengthy. However, the use of fertilizers under conditions of optimum moisture control will increase yields by 4 times and reduce the payback period of the vehicle twice.

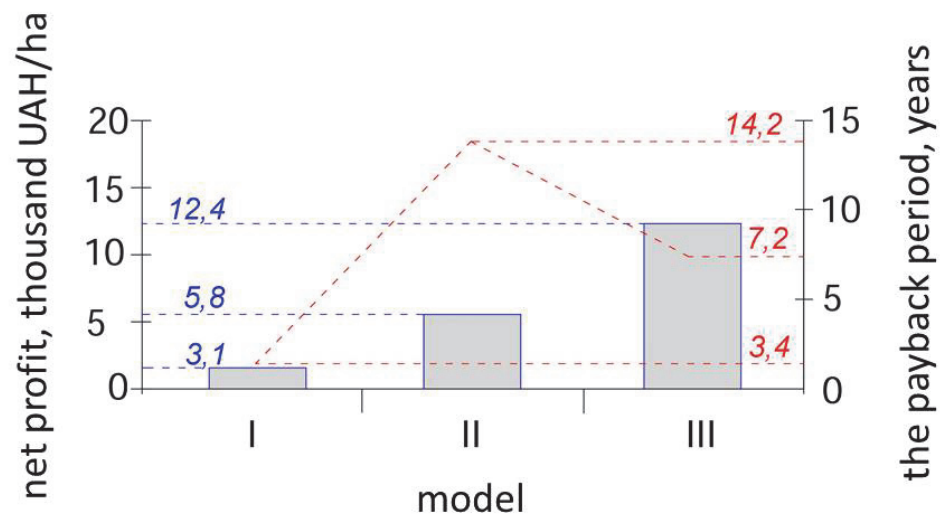

Fig. 3 Economic evaluation of models of intensification of agricultural production Sarny RS NAAN 


\section{Conclusions.}

It is proved that the application of the modular principle operation of the vehicle, it is possible to maintain the necessary level of groundwater drained soils in the range of 0.6-1.1 m during the vegetation period. Simulation results of agricultural production on the studied object indicate that efficient operation of the vehicle and is guaranteed water-air regime of land the profitability of SDS can grow in 4 times. Implementation of the proposed method of operation of the vehicle to a similar system of Western Polissya will leverage more than 1.1 million hectares of existing reclaimed land, with a maximum rate of return to 12 thousand $\mathrm{UAH} / \mathrm{ha}$.

\section{Bibliography}

1. Bio-organic farming systems in the area of drainage. (Recommendations) / edited by corresponding member cor. NAAN Y.O. Tarariko. - Kyiv: DIA, 2013. $167 p$

2. The concept of the effective use of drained lands in humid zone of Ukraine (the scientific basis) / Romashchenko M., Tarariko Y., Yatsyk M. and. [et al.]; IWPiM NAAS, NSC "Institute of agriculture" NAAS, NSC "IG name. Sokolovsky" NAAS etc. - K CPU "Komprint", 2015. - $22 \mathrm{sec}$.

3. Mozol N.V. Design of drainage systems block type / Mozol N.V., B.I. Chaly // Water Management of Ukraine. - 2009. - №3. - S.55-56.

4. Chaly B. Technology regulation of water regime of drained lands using drainage runoff / Chaly. B., Drobot A. // Irrigation and water management. - 2011. - No. 99. - P. 91-97.

5. The formation of the bioenergy agro-ecosystems in the Polissya zone of Ukraine. (Recommendations)Yu Scientific and technological support of agricultural production of left-Bank Polissya. - Kyiv: DIA, 2012. - 248 p.

6. Statistical publication "Agriculture of Ukraine" for 2016 // the State statistics service of Ukraine. 2016. $-68 \mathrm{p}$.

7. Lauren Quinn. What Makes Farmers try new Practices / Lauren Quinn, University of Illinois // Agprofessional magazine. - 2017. Vol.1. Iss. 1. - P. 6-14.

8. Gil Gullickson. Nudge yields with narrow row / Gil Gullickson, Meredith cc. // Successful farming magazine. - 2016. Vol.3. Iss.1. - P. 15-21.

9. Kovalenko P.I. Reconstruction of reclamation systems / Kovalenko P.I., Chaly B.I,, Tyshenko A,I, K .: Urozhay, 1991. - $168 \mathrm{p}$.

10. Saiko V. F. Agriculture in modern conditions // Bulletin of agricultural science. - 2002. - No. 5. S. $1-10$.

11. The transformation of the drained peat soils of Western Polesie for long-term agricultural use / Y.O. Tarariko, L. V. Datsko, N. G. Stetsyuk, M. D. Zasimchuk // Bulletin of agricultural science. - 2016.No. 9. - P. 56-60. 